\title{
The Impact of Foreign Direct Investment on Environmental Degradation: A case study for Mauritius
}

\author{
Zeenat Didorally \& Sheereen Fauzel \\ University of Mauritius
}

\begin{abstract}
The main aim of carrying out this research is to study the impact of foreign direct investment on environmental degradation in Mauritius for a time period from 1976 to 2018. The time series data was used to assess the impact and a Vector Error Correction Model (VECM) was used to estimate the short-run and long-run relationships. To measure environmental degradation in this study, the level of carbon dioxide is being used as a proxy. The findings of this research reveal that the influence of foreign direct investment on environmental degradation is positive and significant in the long-run.
\end{abstract}

Keywords: Foreign Direct Investment, Carbon Dioxide emission, time series data, VECM 


\subsection{INTRODUCTION}

\subsection{Background of the Study}

One of the ultimate desires of every economy is to achieve sustainable economic growth and development. According to UNCTAD, World Investment Report 2019, FDI inflows in Mauritius amounted to USD 433 Million in 2017 and this represents a huge contributor of economic growth. However, at the same time, FDI has an impact on the environmental condition which cannot be ignored. As developing countries continue to grow, their Carbon Dioxide (CO2) emission has become an important issue in international agreements related to FDI and environment. $\mathrm{CO} 2$ emission has grown drastically in the last three decades because of human activities. This has caused a major threat of global warming and climate change has been a major on-going concern for all societies from developing to developed countries (Hossain, 2012).

\subsection{Aim and Objectives of the study}

The main aim of this research is to empirically assess the impact of FDI on environmental degradation for a case study of Mauritius. To measure environmental degradation, CO2 emission will be used as a proxy with the dependent variable which is FDI. The results that will be obtained will reveal whether FDI impact positively or negatively on environmental degradation in Mauritius. To strengthen the research study, other variables such as GDP per capita, energy use, trade openness and GCF will be used to investigate their effects on environmental degradation.

The objectives of the research are therefore:

1. Does FDI positively impact on environmental degradation?

2. Does FDI negatively impact on environmental degradation?

3. Do the other variables; GDP per capita, energy use, trade openness and GCF impact on environmental degradation? 


\subsection{Structure of the thesis}

As depicted in the first chapter, the latter introduces the topic by providing a background study. Chapter 2 illustrates the theories of FDI, its advantages and drawbacks focusing more on contributing to increase environmental degradation. In chapter 3, the dependent and independent variables and the different econometric tests that will be used to test the variables are defined. Chapter 4, represents the data analysis of the relationship between the dependent and independent variables based on the findings. Lastly, chapter 5, shows the conclusion and the recommendation about the problem statement.

\subsection{LITERATURE REVIEW}

\subsection{Theoretical Review}

\subsubsection{Definition of FDI}

According to the OECD and IMF's Balance of Payments manual, fifth edition, "FDI is a category of international investment that reflects the objective of a resident entity in one economy to obtain the lasting interest in an enterprise resident in another economy."

According to the World Bank (2016), there are different types of FDI:

1. Natural resource seeking FDI

One of the most dynamic determinants of FDI has been the richness of natural resources. The companies may have no access to these natural resources in their home-based nation.

2. Market seeking FDI

The parent company in the country of origin being now saturated, so as to gain a path to acquire new customers and greater market share, they move to other countries.

3. Efficiency seeking FDI

The growth in the markets for products and services in industrialised countries indicates higher cost of production. Therefore, to reduce this, firms go in a foreign country to start production in order to take advantage of reduced production costs by using innovative technologies or competing prices of inputs and manpower. 


\section{2nd International Conference on Applied Research in BUSINESS, MANAGEMENT and ECONOMICS}

25_27 September, 2020

Berlin, Germany

4. Strategic asset seeking FDI

Companies go after key resources in a foreign economy, such as trademarks and logos, highly advanced technologies or distribution channels that will enable a firm to strive in a given market and this normally occurs through mergers and acquisitions.

\subsubsection{The extent to which FDI leads to environmental degradation}

The proposition that states FDI leads to economic growth is essentially created on the endogenous growth model, which conveys that overseas investment is allied with several component such as capital, human capital, exports and technology transfers (Borensztein., et al. 1998; Lim., et al. 2000).

These growth-compelling elements could be introduced and also encouraged in order to endorse economic growth through FDI. FDI will rise, which will in turn results from the higher anticipated level of profitability. The levels of total demand for investments in local and overseas will escalate due to higher rates of economic development (Corden 1999 and Zhang 2001).

Furthermore, improved economic achievement proposes improved infrastructural services, an upsurge in employment, increase productivity and greater chances for making profits. In some cases, through the close observation of foreign firms, local firms may increase productivity. In alternate situations, ways of efficient working may be propagated from labour turnover as native workers may move from foreign to local companies. Numerous researches have revealed that more on the job training programs are introduced by foreign firms than the native companies (Ralph B.E, 1975; Reinaldo G, 1986).

Apart from capital inflows and employment which accompany foreign investment, technology transfer for domestic firms may be led by worldwide activities. The spillover efficiency occurs when native businesses are capable to captivate the physical and non-tangible assets of MNCs incorporated in FDI. Above and beyond, as FDI generates backward and forward connections, and MNCs contribute practical support and assistance to native organisations, the level of technology 
of domestic manufacturers is likely to go up (Blomstrom., et al. 1992). If these profits from foreign investment are partly adopted by the penetrating firm, some kind of grant could be acceptable. Conversely, Edwin Mansfield and Anthony Romeo (1980) initiated that only a limited of the 15 MNCs in their study facilitated inland companies to gain modern technological expertise and

knowledge. The absence of spillovers to local businesses was credited to a numerous issues, including inadequate employment of local workforces in higher level job title, too few labour movement among domestic firms and overseas companies, inadequate delegating of works to domestic firms, research and development by the foreign firms were not done and insufficient stimulations by MNCs to propagate their know-how to resident companies.

Without doubt, they invest in more capital-intensive methods of production, employ foreign experts at higher hierarchical level and thus instead of creating work locally, it aggravates the problem as the local manpower remains unemployed. MNCs are large in nature, so when they come to invest here, they can afford to produce and operate at lower costs because they benefit from economies of scale. Consequently, they force local producers to be out of business to gain more monopoly power and later can dominate the market too.

In addition, MNCs may import more of its raw materials from their home country and this has an adverse effect on the balance of payments of the host country. Furthermore, domestic country governments may be manipulated by FDI for grants, subsidies and tax holidays. The latter may also keep on shifting to evade tax and thus not being advantageous.

Similarly, all tendencies of increase in environmental deterioration have been seen in the last decade, such as greenhouse gas emissions ( $\mathrm{CO} 2$ emissions), deforestation and loss of biodiversity. Additionally, movements of natural resource-based supplies and investment are forecasted to increase quicker than economic production. When companies escape ecological rules and protocols when moving, it can be seen that their development is more effectively in terms of a reduction in their costs of production. The chief greenhouse gas, i.e. $\mathrm{CO} 2$ emission is the major wrongdoer that contributes to global warming problems according to some researchers. 
Henceforth, for studying the link between environmental degradation and economic growth the Environmental Kuznets Curve (EKC) is adopted. This method was originally proposed by Kuznets (1955) and it was evolved by Grossman and Krueger (1991) and Selden and Song (1994).

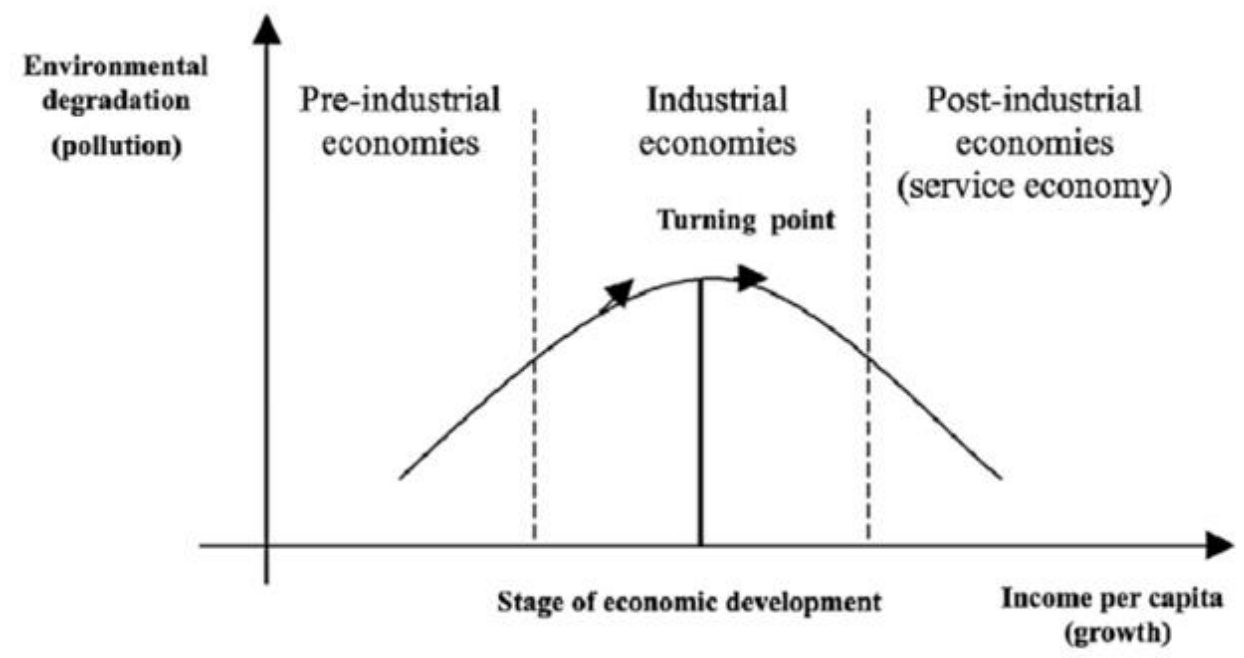

Source: Author's computation

Figure 2.1: Environment Kuznet Curve (EKC)

\subsubsection{Consequences of FDI on environment to host country}

The three various types of viewpoints about the consequence of FDI on the environment of the host state are as follows:

The first aspect is that low-carbon FDI transfers innovative and energy efficient technology, healthier class of equipment, works under improved administrational practices and production procedures to the host state in benefiting the country stimulate the expansion of a low-carbon economy and raise 
environmental quality (Gray, 2002; Perkins and Neumayer, 2008; Talukdar and Meisner, 2001; Wheeler, 2001). It is also denoted as pollution halo hypothesis.

The second category is that FDI undoubtedly boosts up CO2 of the host country and is also referred as PHH (Acharyya, 2009; Grimes and Kentor, 2003; Hoffmann et al., 2005; Javorcik and Wei, 2001; Jorgenson, 2007). In such conditions, MNCs are persuaded to invest in the states which have low level and less strict environmental policies and procedures to boost up their production process. Nevertheless,

poor environmental guidelines and a reduction in the cost of producing commodities are causes of increased pollution in host country. FDI alters economic growth which affects energy consumption and henceforth CO2 in host state (Shahbaz et al., 2015).

Lastly, there is no remarkable consequence on the CO2 of the host country from the side of FDI (Kentor and Grimes, 2006; Perkins and Neumayer, 2009).

\subsection{The effect of FDI on environment in developed and developing countries}

\subsubsection{Environmental impact of FDI in developed countries}

Technological development in industrialised countries have already attained an advanced level. Due to rigorous environmental standards, they commonly use cleaner technologies and more sophisticated environmental-management structures to enhance their FDI activities. On the other hand, it is still feasible that MNCs adopt more environment friendly and innovative technological equipments onward with improved administration and operational systems in the manufacturing chain. Hence, the host country CO2 emission may be diminished by the contribution of FDI (Zarsky, 1999).

\subsubsection{Environmental impact of FDI in developing countries}

FDI will pursue in receiving republics to establish its manufacturing process in countries with less environmental procedures or less strict environmental prosecution rules and regulations. These places establish a basis of reasonable benefit to the pollution-intensive foreign capital (Cole and Elliott, 2005). In relations to the environmental controlling requirements, MNEs will choose inexpensive and more productive countries to increase revenues. Equivalently, host countries may try to soften their 
ecological norms and requirements to draw the attention of FDI. Developing countries intentionally undervalue their ecological norms and requirements to bring in foreign investors. Therefore, to profit from the limited strict environmental procedures, investors in the foreign country usually switch their processes in the poorly unindustrialised nations (Mabey and McNally, 1999).

\subsubsection{Research studies on $\mathrm{CO} 2$ emission and FDI}

More recently, the PHH in BRICS and MINT countries was studied by Qinglong Shao et al. (2019) grounded on VECM approach and ended with a comparison that inward FDI investment may ameliorate instead of contaminating the eco-system in the future years.

Similarly, Muhammed Sehid Gorus and Murat Aslan (2018), make founding on effects of economic indicators on environmental degradation. They found that FDI inflow upsurges environmental degradation in Algeria, Iran, Jordan, Morocco, and Turkey in the long-run but in Iran, Sudan, Tunisia, and Turkey a negative effect of energy consumption on pollution is observed.

One of the most prominent studies on the subject FDI and $\mathrm{CO} 2$ emission was carried out by Sheereen Fauzel (2017) in Mauritius using the ARDL model. When analyzing, her results have proved that FDI in the manufacturing sector increase $\mathrm{CO} 2$ emission but it is not the case for FDI in the nonmanufacturing sector.

The effects of FDI and income on pollution emissions were studied by Pratikshya Sapkota and Umesh Bastola (2017) as from 1980 to 2010 for 14 Latin American states using time series data. When examining, they discovered that FDI is indeed linked with pollution positively, which upholds the PHH for these areas.

Muhammad Shahbaz et al. (2018) also evaluate the link between FDI and CO2 emissions in a French carbon emissions function. They conclude that a rise in FDI degrades the environmental condition by boosting carbon emissions. 
Mizan Bin Hitam and Halimahton Binti Borhan (2012) examined the two most vital gains and drawbacks of FDI in the Malaysian framework that is GDP growth and the environmental damage. The empirical consequences reveal that FDI is a significant element of the environmental degradation and results state that EKC exists.

Joao Paulo Cerdeira Bento and Antonio Moreira (2017) desire to evaluate how foreign capital and subsidiary FSAs of US MNEs' majority-owned subsidiaries affect host countries natural atmosphere.

In developing countries, FDI is positive, which conveys proof of supporting the PHH. Conversely, FDI is significantly desirable in industrialized countries, signifying that FDI will lessen environmental degradation of the host country, supporting the pollution halo hypothesis in developed republics.

Berna Kirkulak et al. (2011) aim at evaluating the effect of FDI on air pollution from 2001 to 2007 using 286 towns in China. The findings divulge that FDI has a negative influence on CO2 emission signifying that air pollution reduces by the size of foreign capital flows which is backed by the hypothesis of pollution halo.

Shenggang Ren et al. (2013) estimates CO2 emissions illustrated in China international trade using an input-output analysis, for the period 2000-2010. They conclude that the overall outcome of foreign activities is not positive for China since it rises $\mathrm{CO} 2$ emission, and FDI has a significant positive impact on $\mathrm{CO} 2$ emissions.

\subsection{METHODOLOGY}

\subsection{Introduction}

The relationship between FDI and $\mathrm{CO} 2$ emission are studied in this research paper whilst integrating Foreign Direct Investment, GDP per capita, Trade Openness, Energy Use and Gross domestic Capital Formation in Mauritius over a period of 42 years from 1976 to 2018. Based on empirical results of preceding research papers and recent studies too, a long-run relationship among these variables is feasible to conduct a research. 


\subsection{Formation of the hypotheses}

Since the fundamental purpose of this research is to determine to what extent FDI leads to environmental degradation, the following hypotheses were formed:

H0: FDI does not increase CO2 emission

H1: FDI increase CO2 emission

\subsection{Model Specification}

Following the theory from earlier debates, we model the general carbon dioxide emission function as follows:

$$
C O 2_{t}=\beta_{0}+\beta_{1} F D I_{t}+\beta_{2} G D P_{t}+\beta_{3} E U_{t}+\beta_{4} T O_{t}+\beta_{5} G C F_{t}+\varepsilon_{t}
$$

Where,

$\mathrm{CO} 2=$ Carbon Dioxide emission,

FDI $=$ Foreign Direct Investment,

GDP $=$ Gross Domestic Product (per capita),

$\mathrm{EU}=$ Energy Use,

$\mathrm{TO}=$ Trade Openness,

GCF $=$ Gross domestic Capital Formation,

$\beta_{0}=$ Constant term,

$\mathrm{t}=$ Years from the time frame,

$\varepsilon=$ Random disturbance term. 


\subsection{1 $\log (\mathrm{L})$ Transformation}

For the purpose of this study, the equation was transformed into log form in order to make highly skewed distributions less skewed and make the data more interpretable. The equation is therefore as follows:

$$
L C O 2_{t}=\beta_{0}+\beta_{1} L F D I_{t}+\beta_{2} L G D P_{t}+\beta_{3} L E U_{t}+\beta_{4} L T O_{t}+\beta_{5} L G C F_{t}+\varepsilon_{t}
$$

\subsection{Dependent variable}

\subsubsection{CO2 emission}

Our dependent variable is a means of measuring environmental performance (degradation). $\mathrm{CO} 2$ emission has been taken up as a proxy for pollution release and this is indicated in metric tons per capita.

\subsection{Independent variables}

\subsubsection{Foreign direct investment (FDI)}

Foreign direct investment is a form of "worldwide investment initiated by an inhabitant in a country (i.e., direct investor) whose main aim is the establishment of a long-standing interest in an organisation (i.e., direct investment enterprise) that exists in a different economy from that of the direct investor".

\subsubsection{Gross Domestic Product (GDP)}

Gross domestic product is the "total of gross value added by all local manufacturers in the country in addition to any product taxes and minus any grants not involved in the price of the goods". This variable is a proxy for economic growth. Rapid growing in production and consumption may have a harmful effect on environmental pollution. 


\subsubsection{Energy Use (EU)}

Energy consumption denotes to "the usage of primary energy before converting it to other end-use energies".

\subsubsection{Trade Openness (TO)}

Trade openness is characterised as the "total sum of imports and exports divided by the GDP".

\subsubsection{Gross domestic Capital Formation (GCF)}

Gross domestic Capital Formation implies that an economy moves aside a proportion of its existing productive activity in the production of capital goods such as building, plant and equipment, transport facilities, tools and instruments, machines and other various types of real capital that can boost up productive effort efficiency.

\subsection{Econometric Tests}

For a reasonable conclusion to be reached, several econometric tests were being performed. In order to test the data obtained from the World Bank, Eviews 10 will be used.

\subsubsection{Descriptive Statistics}

Descriptive statistics are of paramount importance for the reason that, if raw data is merely shown, it would be difficult to visualize what the latter was demonstrating. Especially, in a research, the variables that are generally measured are numerous. Therefore, it makes the interpretation of the data more obvious and straightforward.

\subsubsection{Unit Root}

Unit root tests are applied in order to detect stationarity properties of the regression. Before performing a co-integration test, it is essential to conduct a primary stage of investigating in case the variables comprise of a unit root. 
There are several classical unit root tests that are used in order to wipe out the existence of nonstationary, for instance, the Dickey and Fuller (AD, 1979), Augmented Dickey-Fuller (ADF) and Phillips-Perron (PP) can be adopted.

\subsubsection{Cointegration Test}

Cointegration test is used to observe whether two or more combined variables deviate significantly from a certain relationship (Abadir and Taylor, 1999). Series that are integrated at order one turn out to be stationary only after being differenced once.

\subsubsection{Vector Error Correction Model}

Engle and Granger (1987) exposed by the error-representation theorem that cointegrated variables indicates in effect an error correction model (ECM). He claimed that a misspecification error will be resulted if the regression is of the first difference of cointegrated variables. Therefore, to analyse the changing aspects of the relationship, the VAR was formulated in a Vector Error Correction Model (VECM).

Thus, the VECM to analyse the short-run and long-run causal relationship between FDI and environmental degradation is defined as:

$$
\begin{gathered}
\operatorname{LCO}_{t}=\propto_{0}+\sum_{j=1}^{n} \propto_{1} \Delta \operatorname{LFDI}_{t \cdot j}+\sum_{j=1}^{n} \propto_{2} \Delta L G D P_{t \cdot j}+\sum_{j=1}^{n} \propto_{3} \Delta L E U_{t \cdot j}+\sum_{j=1}^{n} \propto_{4} \Delta L T O_{t \cdot j}+ \\
\sum_{j=1}^{n} \propto_{5} \Delta L G C F_{t-j}+{ }^{n} e c t_{t-1}+\varepsilon_{t}
\end{gathered}
$$

Where:

ect $t_{\mathrm{t}-1}=$ Coefficient of the error term representing the existence of a short-run relationship among the time series variables.

$\mathrm{t}(\mathrm{t}=1, \mathrm{~T})=$ Number of years . 
$\mathrm{j}=$ Optimum lag.

$\Delta=$ Difference operator.

$e_{t-1}=$ Lagged error correction term derived from the long-run cointegrating relationship.

$\varepsilon_{\mathrm{t}}=$ Disturbance term assumed to be uncorrelated white noises.

\subsection{FINDINGS AND ANALYSIS}

\subsection{Introduction}

This chapter will illustrate the various tests conducted and their analysis accordingly to the research topic.

\subsection{Diagnostic Tests and Descriptive Statistics Results}

From the table, it can clearly be seen that the probability of Jarque-Bera is greater than $10 \%$ which means that the data chosen for this research is normal. So, further tests can be carried out with this data and results would not be bias.

Table 4.1: Descriptive Statistics

\begin{tabular}{|l|l|l|l|l|l|l|}
\hline & LGCO2 & LGFDI & LGGDP & LGENERGY & LGTRADE & LGGCF \\
\hline Mean & 0.453160 & -0.115070 & 8.108441 & 6.572195 & 4.737770 & 3.200851 \\
\hline Median & 0.548325 & -0.139563 & 8.195062 & 6.561574 & 4.744200 & 3.217427 \\
\hline Maximum & 1.209888 & 1.739835 & 9.327118 & 7.048020 & 4.920799 & 3.458815 \\
\hline
\end{tabular}


2nd International Conference on Applied Research

25_27 September, 2020 in BUSINESS, MANAGEMENT and ECONOMICS

Berlin, Germany

\begin{tabular}{|l|l|l|l|l|l|l|}
\hline Minimum & -0.680893 & -2.834100 & 6.654983 & 6.027319 & 4.539518 & 2.860173 \\
\hline $\begin{array}{l}\text { Standard } \\
\text { Deviation }\end{array}$ & 0.647572 & 1.166253 & 0.829061 & 0.353610 & 0.108995 & 0.177278 \\
\hline Skewness & -0.383123 & -0.283621 & -0.168774 & -0.155028 & -0.174998 & -0.314384 \\
\hline Kurtosis & 1.601940 & 2.300058 & 1.752334 & 1.525917 & 1.921769 & 2.111531 \\
\hline Jarque-Bera & 4.447983 & 1.420443 & 2.923567 & 3.970845 & 2.248891 & 2.073268 \\
\hline Probability & 0.108176 & 0.491535 & 0.231822 & 0.137323 & 0.324832 & 0.354646 \\
\hline Sum & 19.03272 & -4.832939 & 340.5545 & 276.0322 & 198.9864 & 134.4357 \\
\hline $\begin{array}{l}\text { Sum } \\
\text { SquareDeviation }\end{array}$ & 17.19334 & 55.76601 & 28.18100 & 5.126628 & 0.487073 & 1.288528 \\
\hline
\end{tabular}

Source: Authors computation

\subsection{Unit Root Test}

The results obtained are shown below and the hypotheses formulated are as follows:

H0: Variables have a unit root (non-stationary)

H1: Variables do not have a unit root (stationary)

Table 4.2: Unit Root test results

\begin{tabular}{|l|l|l|l|l|}
\hline \multirow{2}{*}{ Variables } & \multicolumn{2}{|l|}{ Unit Root test at level } & \multicolumn{2}{l|}{ Unit Root test at first difference } \\
\cline { 2 - 5 } & t-Statistics & Probability & t-Statistics & Probability \\
\hline CO2 & -0.731616 & 0.8275 & -5.304165 & 0.0001 \\
\hline FDI & -1.634450 & 0.4561 & -6.763674 & 0.0000 \\
\hline GDP & -1.058834 & 0.7230 & -4.966416 & 0.0002 \\
\hline Energy & -0.210311 & 0.9291 & -5.387176 & 0.0001 \\
\hline Trade & -1.534739 & 0.5065 & -5.846356 & 0.0000 \\
\hline GCF & -2.582106 & 0.1046 & -8.022186 & 0.0000 \\
\hline
\end{tabular}

Source: Author's computation

After converting the variables into their first difference, the ADF test statistics reject the null hypothesis at $5 \%$ significance level in all cases. Thus, this model can now be more accurate and reliable and can continue to perform other tests. 


\subsection{Cointegration Test}

To test for the variables that are going to be used, the Johansen cointegration test was selected. The table below shows the results that have been obtained using the Johansen cointegration test. The hypotheses formulated are as follows:

H0: No cointegration

H1: Cointegration

The findings approved that both the Trace Test and the Max-Eigen value indicate that there is the presence of one cointegrating equation. It is quite obvious that the null hypothesis of no rank is rejected.

Hence, the Johansen cointegration test confirms that there is a lasting long run relationship between $\mathrm{CO} 2$ emission and other variables at 5\% significance level in Mauritius during 1976 to 2018.

\subsection{Vector Error Correction Estimates}

For the purpose of this study, we have chosen an optimal lag of 1 because we have 1 cointegrating vector (Johansen cointegrating vector). The table below shows the long run results that have been obtained using the VECM.

Table 4.3: VECM Long Run Results

\begin{tabular}{|l|l|l|}
\hline Cointegrating Equation & Coefficient & T-Statistics \\
\hline CO2 (-1) & 1.000000 & \\
\hline FDI $(-1)$ & 0.089316 & $2.13444 * *$ \\
\hline GDP $(-1)$ & -0.0000564 & -1.24241 \\
\hline Energy (-1) & 0.004344 & $8.75951 * * *$ \\
\hline Trade $(-1)$ & 0.018621 & $4.94142 * * *$ \\
\hline GCF $(-1)$ & -0.025279 & $-2.41551^{* * *}$ \\
\hline
\end{tabular}

Source: Author's computation

**: $5 \%$ siginificance level

***: $1 \%$ significance level 


\subsubsection{Relationship between $\mathrm{CO} 2$ emission and FDI}

The rise of the $\mathrm{CO} 2$ emission is positively related to FDI and thus, the estimated model was able to produce a consistent result.

From the results obtained, the coefficients of the long-run relationship between $\mathrm{CO} 2$ emission and FDI are positive and significant at 5\% significance level. Therefore, we can clearly say that a 1 percent increase in FDI is associated with 0.089 percent increase in CO2 emissions. Such a result is consistent with the findings of P.Sapkota and U.Bastola (2017) in 14 Latin American countries, M.Shahbaz et al. (2018) in France, M.B.Hitam and H.B.Borhan (2012) in Malaysia, S.Ren et al. (2013) in China and S.Fauzel (2017) in Mauritius.

Relating to this result here, it is to be noted that there has been a massive inflow of FDI in Mauritius. Especially, the private sector investment increased mostly in sector like tourism, the Integrated Resort Scheme (IRS) and finance which has led to the detrimental of our natural forests and thus increase the level of pollution.

Furthermore, this result can also be clarified by the rise of FDI in the manufacturing sector. FDI in the mid-1980s has a favourable performance which was directed by the Export Processing Zone (EPZ) programme, and fascinated enough to bring in two-thirds of all FDI inflows, mostly from Asia and focused on knitwear and garments production. The government did not impose any regulations on them to obtain all these benefits but at the same time increasing the level of polluted air.

\subsubsection{Relationship between $\mathrm{CO} 2$ emission and local investment}

Further concentrating into the result obtained, it is to be assumed that a 1 percent rise in GDP will cause the level of pollution to fall by a very small amount of around 0.00005 percent and the coefficient obtained is quite insignificant. Similarly, 1 percent increase in GCF will impact negatively on CO2 by an amount of 0.025 percent and the coefficient result is significant at $1 \%$ significance level. This result for GCF is similar to what S.Fauzel (2017) found for the case of FDI in the non-manufacturing sector in Mauritius. 
Such outcomes were certainly anticipated for local companies as the government impose stricter rules and regulations on them when they manufacture economic output. The government impose that these factors of production must be increased or used more efficiently in order to achieve real economic

growth. Furthermore, with the concept of Maurice Ile Durable, acknowledged in 2008 after the financial crisis 2007, the use of green energy is strengthened. Subsequently, the above outcomes, truly validate that $\mathrm{CO} 2$ has reduced in local investment.

\subsubsection{Relationship between $\mathrm{CO} 2$ emission and Energy Use}

Alternatively, in our research analysis, a 1 percent increase in energy use have a direct impact on $\mathrm{CO} 2$ emission which increase it by 0.0043 percent and coefficient is significant at $1 \%$ significance level. This observed indication is same as to what Iwata et al. (2010) obtained for France, Saboori et al. (2012, 2016) for Malaysia, Al-Mulali et al. (2015) for Vietnam, and Shahbaz et al. (2017) for the US.

Human actions are the greatest cause of $\mathrm{CO} 2$ emission and they release fossil fuels during consumption. Since the revolutionary period, the use of fossil fuel has amplified intensely (Boden et al., 2011).

Mauritius's energy necessity has grown at an annual rate of 5\% throughout the last decade and has turn out to be more and more dependent on the use of fossil fuels. In Mauritius this outcome is well expected since most of the energy use is fossil fuels and the burning of the latter lead to environmental degradation.

\subsubsection{Relationship between $\mathrm{CO} 2$ emission and Trade Openness}

Probing deeper into the analysis, an increase in trade openness by 1 percent is explained by an increased in $\mathrm{CO} 2$ by 0.019 as shown in the above table and this result is significant at $1 \%$ significance level. Such a result is consistent with the findings of V. Sannassee and B. Seetanah for Mauritius (2016) and H.M Ertugrul, M.Cetin, F.Seker, E.Dogan for Turkey, India, China and Indonesia (2016).

Trade openness is indeed anticipated to have a positive impact on $\mathrm{CO} 2$ emission in Mauritius, more precisely because of the fact that most of our exported goods are principally textiles goods. Due to changing demand and fashion of these products, the textile industry produces clothes immensely. The 
textile industry produces pollutants from boilers, thermo pack, and diesel generators that are discharged into the atmosphere which caused the root of problem, that is, $\mathrm{CO} 2$ emission rise as production increases.

\subsection{Error Correction Term}

\section{Table 4.6: ECT}

\begin{tabular}{|l|l|}
\hline Error Correction & $\mathrm{D}(\mathrm{CO} 2)$ \\
\hline CointEq1 & -0.230739 \\
\hline
\end{tabular}

Source: Author's computation

The previous periods deviation from long run equilibrium is correlated at the speed of $23 \%$. The short run results have not been reported because they are insignificant. This is so, because the dependent variable, $\mathrm{CO} 2$ emission takes time to have its full effect on the other dependent variables. For instance, when there is an increase in FDI now, pollution is not caused immediately, that is, $\mathrm{CO} 2$ emission does not increase instantly. It takes time and incurred in the long run.

\subsection{CONCLUSION AND POLICY RECOMMENDATIONS}

\subsection{Conclusion}

The ultimate goal of this research study is to empirically examined the impact of FDI on CO2 emission for Mauritius by using annual time series data over a sample time period of 42 years (1976-2018). The VECM was applied to know whether FDI impact positively or negatively on environmental damage, more specifically air pollution. To be better able to capture the effect of FDI on CO2 emission, other variables such as GDP per capita, energy use, trade openness and GCF were being adopted.

The finding of the study therefore affirmed that FDI impact positively and significantly on $\mathrm{CO} 2$ emission in Mauritius in the long-run. 


\subsection{Policy recommendations}

From the analytical results, the following points may be suggested to implement in order to control $\mathrm{CO} 2$ emission in Mauritius.

The policymakers and the government need to implement strictly environmental rules and regulations to foreign firms and deploy measures to encourage sustainable development in Mauritius. In addition, the government need to promote the "green industry", that is, provide incentives to foreign firms that are reducing environmental pollution, manufacture eco-friendly goods and using efficient technology. Also, policymakers should focus on aggressive education and awareness campaign to the society. Last but not the least, the government should encourage more foreign firms investing here especially in the

non-manufacturing industry who have the concept of "work from home" whereby this will reduce the level of carbon emissions from traffic congestion.

\section{BIBLIOGRAPHY}

ACAR, Y., GÜRDAL, T. and EKERYILMAZ, Ş., 2018. Environmental Kuznets Curve for CO2 emissions: An analysis for developing, Middle East, OECD and OPEC countries. Environmental \& Socio-economic Studies, 6(4), pp.48-58.

ACHARYYA, J., (2009). FDI, growth and the environment: Evidence from India on CO2 emission during the last two decades. Journal of Economic Development.

AITKEN, B. and HARRISON, A., 1999. Do Domestic Firms Benefit from Direct Foreign Investment? Evidence from Venezuela. American Economic Review, 89(3), pp.605-618.

ALBULESCU, C., TIWARI, A., YOON, S. and KANG, S., 2019. FDI, income, and environmental pollution in Latin America: Replication and extension using panel quantiles regression analysis. Energy Economics, 84, p.104504. 
ASGHARI, M., 2013. Does FDI Promote MENA Region's Environment Quality? Pollution Halo or Pollution Haven Hypothesis. International Journal of Scientific Research in Environmental Sciences, 1(6), pp.92-100.

BAKHSH, K., ROSE, S., ALI, M., AHMAD, N. and SHAHBAZ, M., 2017. Economic growth, CO 2 emissions, renewable waste and FDI relation in Pakistan: New evidences from 3SLS. Journal of Environmental Management, 196, pp.627-632.

BOOPEN, S. and VINESH, S., 2011. On the relationship between CO2 emissions and economic growth: the Mauritian experience, in CSAE 25th Anniversary Conference, 1e25.

CERDEIRA BENTO, J. and MOREIRA, A., 2019. Environmental impact of FDI - the case of US subsidiaries. Multinational Business Review, 27(3), pp.226-246.

CETIN, M., 2017. Investigating the environmental Kuznets Curve and the role of green energy: Emerging and developed markets. International Journal of Green Energy, 15(1), pp.37-44.

COLE, M., ELLIOTT, R. and FREDRIKSSON, P., 2005. Endogenous Pollution Havens: Does FDI Influence Environmental Regulations? SSRN Electronic Journal.

DANISH, BALOCH, M., MAHMOOD, N. and ZHANG, J., 2019. Effect of natural resources, renewable energy and economic development on CO2 emissions in BRICS countries. Science of The Total Environment, 678, pp.632-638.

DEMENA, B. and AFESORGBOR, S., 2020. The effect of FDI on environmental emissions: Evidence from a meta-analysis. Energy Policy, 138, p.111192.

ERTUGRUL, H., CETIN, M., SEKER, F. and DOGAN, E., 2016. The impact of trade openness on global carbon dioxide emissions: Evidence from the top ten emitters among developing countries. Ecological Indicators, 67, pp.543-555. 
FAUZEL, S., 2017. The impact of FDI on CO2 emission in a small island developing state: A cointegration approach. Economics and Business Letters, 6(1), 6-13.

GORUS, M. and ASLAN, M., 2019. Impacts of economic indicators on environmental degradation: Evidence from MENA countries. Renewable and Sustainable Energy Reviews, 103, pp.259-268.

HAO, Y. and LIU, Y., 2014. Has the development of FDI and foreign trade contributed to China's CO2 emissions? An empirical study with provincial panel data. Natural Hazards, 76(2), pp.1079-1091.

HITAM, M. and BORHAN, H., 2012. FDI, Growth and the Environment: Impact on Quality of Life in Malaysia. Procedia - Social and Behavioral Sciences, 50, pp.333-342.

HOFFMANN, R., LEE, C., RAMASAMY, B. and YEUNG, M., 2005. FDI and pollution: a granger causality test using panel data. Journal of International Development, 17(3), pp.311-317.

HOSSAIN, S., 2012. An Econometric Analysis for CO2 Emissions, Energy Consumption, Economic Growth, Foreign Trade and Urbanization of Japan. Low Carbon Economy, 03(03), pp.92-105.

JUGURNATH, B. and EMRITH, A., 2018. Impact of Foreign Direct Investment On Environment Degradation: Evidence From SIDS Countries. The Journal of Developing Areas, 52(2), pp.13-26.

KHOODARUTH, A., OREE, V., ELAHEE, M. and CLARK, W., 2017. Exploring options for a 100\% renewable energy system in Mauritius by 2050. Utilities Policy, 44, pp.38-49.

KIRKULAK, B., QIU, B. and YIN, W., 2011. The impact of FDI on air quality: evidence from China. Journal of Chinese Economic and Foreign Trade Studies, 4(2), pp.81-98.

KISTO, M., 2017. Determinants of Foreign Direct Investment in Mauritius: Evidence From Time Series Data. International Journal of Scientific \& Technology Research, pp.2277-8616. 
KIVYIRO, P. and ARMINEN, H., 2014. Carbon dioxide emissions, energy consumption, economic growth, and foreign direct investment: Causality analysis for Sub-Saharan Africa. Energy, 74, pp.595606.

KOSTEVC, Č., REDEK, T. and SUŠJAN, A., 2007. Foreign Direct Investment and Institutional Environment in Transition Economies. Transition Studies Review, 14(1), pp.40-54.

LAU, L., CHOONG, C. and ENG, Y., 2014. Investigation of the environmental Kuznets curve for carbon emissions in Malaysia: Do foreign direct investment and trade matter? Energy Policy, 68, pp.490497.

MUHAMMAD, B. and KHAN, S., 2019. Effect of bilateral FDI, energy consumption, CO2 emission and capital on economic growth of Asia countries. Energy Reports, 5, pp.1305-1315.

PAO, H. and TSAI, C., 2011. Multivariate Granger causality between CO2 emissions, energy consumption, FDI (foreign direct investment) and GDP (gross domestic product): Evidence from a panel of BRIC (Brazil, Russian Federation, India, and China) countries. Energy, 36(1), pp.685-693.

PAZIENZA, P., 2014. The Relationship Between FDI and the Natural Environment. Springer Briefs in Economics.

REN, S., YUAN, B., MA, X. and CHEN, X., 2014. International trade, FDI (foreign direct investment) and embodied CO2 emissions: A case study of Chinas industrial sectors. China Economic Review, 28, pp.123-134.

SAINI, N. and SIGHANIA, M., 2019. Environmental impact of economic growth, emission and FDI: systematic review of reviews. Qualitative Research in Financial Markets, 11(1), pp.81-134.

SALEH, K., 1997. The measurement of gross domestic fixed capital formation in Indonesia. OECD. 
SANNASSEE, R. and SEETANAH, B., 2016. Trade Openness and CO2 Emission. Handbook of Environmental and Sustainable Finance, 165-177.

SAPKOTA, P. and BASTOLA, U., 2017. Foreign direct investment, income, and environmental pollution in developing countries: Panel data analysis of Latin America. Energy Economics, 64, pp.206212.

SEKER, F., ERTUGRUL, H. and CETIN, M., 2015. The impact of foreign direct investment on environmental quality: A bounds testing and causality analysis for Turkey. Renewable and Sustainable Energy Reviews, 52, pp.347-356.

SHAHBAZ, M., NASIR, M. and ROUBAUD, D., 2018. Environmental degradation in France: The effects of FDI, financial development, and energy innovations. Energy Economics, 74, pp.843-857.

SHAO, Q., WANG, X., ZHOU, Q. and BALOGH, L., 2019. Pollution haven hypothesis revisited: A comparison of the BRICS and MINT countries based on VECM approach. Journal of Cleaner Production, 227, pp.724-738.

SHAO, Y., 2018. Does FDI affect carbon intensity? New evidence from dynamic panel analysis. International Journal of Climate Change Strategies and Management, 10(1), pp.27-42.

SULEMANA, I., JAMES, H. and RIKOON, J., 2016. Environmental Kuznets Curves for air pollution in African and developed countries: exploring turning point incomes and the role of democracy. Journal of Environmental Economics and Policy, 6(2), pp.134-152.

WASLEKAR, S., 2014. World Environmental Kuznets Curve and the Global Future. Procedia - Social and Behavioral Sciences, 133, pp.310-319.

YU, Y. and XU, W., 2019. Impact of FDI and R\&D on China's industrial CO2 emissions reduction and trend prediction. Atmospheric Pollution Research, 10(5), pp.1627-1635. 
ZHANG, C. and ZHOU, X., 2016. Does foreign direct investment lead to lower CO2 emissions? Evidence from a regional analysis in China. Renewable and Sustainable Energy Reviews, 58, pp.943951.

ZHANG, J. and FU, X., 2008. FDI and environmental regulations in China. Journal of the Asia Pacific Economy, 13(3), pp.332-353.

ZHENG, J. and SHENG, P., 2017. The Impact of Foreign Direct Investment (FDI) on the Environment: Market Perspectives and Evidence from China. Economies, 5(1), p.8.

ZOU, X., 2018. VECM Model Analysis of Carbon Emissions, GDP, and International Crude Oil Prices. Discrete Dynamics in Nature and Society, 2018, pp.1-11. 